\title{
PRIVACY CALCULUS: FACTORS THAT INFLUENCE THE PERCEPTION OF BENEFIT
}

\section{Cesión calculada de información personal: factores que influyen en la percepción de beneficio}

José-Luis Gómez-Barroso, Claudio Feijóo and Inmaculada J. Martínez-Martínez

Nota: Este artículo se puede leer en español en:

http://www.elprofesionaldelainformacion.com/contenidos/2018/mar/12_esp.pdf
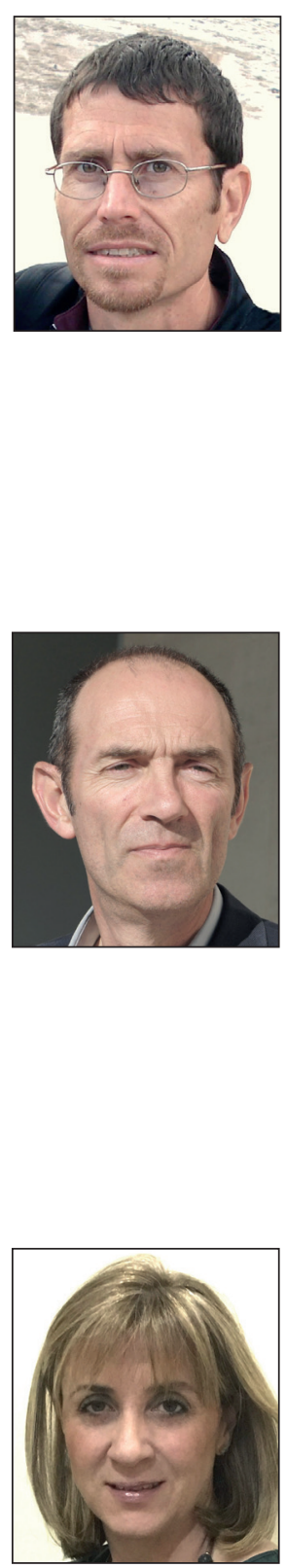

José-Luis Gómez-Barroso, professor of the Department of Applied Economics and Economic History at the Universidad Nacional de Educación a Distancia (UNED), holds a Ph.D. and A MSC in Economic and Business Sciences from UNED, a MSc in Telecommunication Engineering from the Universidad Politécnica of Madrid, and also holds a MA in Law from the Universidad Complutense de Madrid (UCM). He works in economics and the regulation of the convergent sector of information and communication technologies, and in factors that influence the development of the information society. $\mathrm{He}$ is the lead investigator of the project "Understanding personal information-driven markets", financed by the Ministerio de Economía y Competitividad through the National program of research, development and innovation oriented toward societal challenges (ECO2013-47055-R), of which this article is a result.

http://orcid.org/0000-0001-9259-4915

Universidad Nacional de Educación a Distancia (UNED) Dpto. Economía Aplicada e Historia Económica Po Senda del Rey, 11. 28040 Madrid, Spain jlgomez@cee.uned.es

Claudio Feijóo holds a MSc and PhD in Telecommunication Engineering and a MSc in Quantitative Economics. He is full professor at the Polytechnical University of Madrid (UPM) where he researches on the future socio-economic impact of emerging information society technologies. Since 2014 he lives in China where he serves as Co-Director of the Sino-Spanish Campus at Tongji University in Shanghai as well as responsible for Asia affairs at UPM. Among his main experience he spent two years at the Institute for Prospective Technological Studies of the European Commission researching on the future prospects of mobile content and applications. For three years he was dedicated to launch a university spin-off devoted to the transfer of know-how in technology, media and telecommunications. He has also been involved in numerous projects in Europe, Latin America, North of Africa and Asia-Pacific. He has authored more than 250 publications in books, journals and conferences. He is member of the board of the International Telecommunications Society. http://orcid.org/0000-0002-9499-7790

Tongji University. Sino-Spanish Campus, Yifu Building, Office 210 1239 Siping Road. 200092 Shanghai, P. R. China claudio.feijoo@upm.es

Inmaculada J. Martínez-Martínez has a PhD in Communication (Advertising) from the Complutense University in Madrid, and a MA in Marketing from the Know How Business School. She is a professor at the School of Communication and Information Studies, University of Murcia (Spain), where she teaches Advertising Ecosystem. Her publications include "Mobile society: Culture, identity \& technology" (2008), "Mobilized: Women \& mobile in the information society" (2010); "Mobile communications: Towards a new media ecosystem" (2013) and "Emerging perspectives on the mobile content ecosystem" (2015). She is co-ordinating the R+D project "Mobile communications and personal data: Impact in media industry, advertising system and users' perceptions" (CSO2013-47394-R) as well as the project "MOB AD: The impact of mobile technology in strategic communication and advertising" (19451/PI/14) with researchers from Spain, UK, USA, Australia and China.

http://orcid.org/0000-0003-3807-1325

Universidad de Murcia, Facultad de Comunicación y Documentación 30100 Espinardo (Murcia), Spain inmartin@um.es 


\begin{abstract}
In many cases, users of online applications and services consciously and willingly hand over personal data to obtain a better service or a price reduction. This action assumes - nominally - that they behaved rationally, estimating and comparing benefits and costs (the potential use of their data and to whom it might be given). People have different perceptions about the benefits that result from handing over personal data. This article investigates the factors that influence this differing perception and concludes that those who are addicted to the internet, whose confidence has not been damaged in the past, with less knowledge, and who are more active on the internet are prone to perceive a greater benefit.
\end{abstract}

\title{
Keywords
}

Personal data; Personal information; Privacy; Perceived benefit; Privacy calculus; Customisation; Personalization; Information disclosure; Trade-off; User behaviour; Rationality; Motivation; Online; Consumers.

\section{Resumen}

En muchas ocasiones, los usuarios de aplicaciones y servicios en internet ceden consciente y voluntariamente sus datos personales para obtener una mejora en el servicio o una reducción en el precio. Esta acción implica, en principio, que han seguido un comportamiento racional calculando y luego confrontando los beneficios que se les ofrecen y los costes implícitos (el uso potencial que de sus datos pueda hacerse). La percepción del beneficio derivada de la cesión de información personal no es igual para todos los individuos. Este artículo investiga los factores que la determinan y concluye que son más proclives a percibir mayor beneficio los más adictos a la Red, los que no han perdido su confianza por haber sufrido en el pasado algún incidente desagradable en internet, quienes menos conocimientos tienen, y quienes desarrollan una mayor actividad online.

\section{Palabras clave}

Datos personales; Información personal; Privacidad; Percepción de beneficio; Cesión calculada; Personalización; Comportamiento; Usuarios; Racionalidad; Motivación; Consumidores.

Gómez-Barroso, José-Luis; Feijóo, Claudio; Martínez-Martínez, Inmaculada J. (2018). “Privacy calculus: Factors that influence the perception of benefit". El profesional de la información, v. 27, n. 2, pp. 341-348.

https://doi.org/10.3145/epi.2018.mar.12

\section{Introduction}

The ease with which we reveal information about ourselves is one of the most profound social changes that have occurred (or better, are occurring) in recent years. In a world in which all kinds of relationships, including personal ones, are developed more and more by telematic means, absolute anonymity becomes a utopia because in this activity it is almost impossible not to leave any trace of who we are and what we do. This information can be collected (and often is, especially by companies) without us being aware of it. However, on many occasions we are the ones who give data, we even give more data than would be strictly necessary for a simple exchange to occur.

Obviously, all behaviour has a cause. It seems clear that conscious and voluntary acts carry a reward of varying kinds. And also that this reward overcomes the potential inconveniences that such an act could entail. This is at least in a scenario of rationality in which the individual is able to identify benefits and harm. That scenario is more likely depending on the frequency of the action in question. Accordingly, if a few years ago the users of services and applications on the Internet were not able to assess the scope of their actions, today a good part of them are expert enough to be able to assume that they are in a position to assess them.

In the case of the transfer of personal information, this hypothesis means that individuals should confront benefits and damage and act accordingly: be more likely to reveal data when the positive overcomes the negative or otherwise take action to protect their privacy. In other words, this calculation of how "profitable" it is to reveal data should have an influence on their behaviour. In any imaginable possible situation, the inconvenience associated with transferring data is always the same: a potential invasion of privacy. On the other hand, the benefits are varied and range from the psychological or relational (in the case of social networks) to the attainment of an improved service, in particular by the adaptation possible when tastes and needs have been provided.

This last case is the one that interests us in this article, whose objective is to conclude if the usefulness derived from personalised services and applications is perceived by the users, and if this influences their attitude towards revealing private information or not. For this we use data obtained from a survey conducted in September 2016 with a representative cross-section of the Spanish Internet user. This work is part of the research area that for just ten years has been studying the behaviour of users with respect to the protection of their privacy on the internet, and it is structured as follows: the next section reviews this bibliography, specifically the one related to the "privacy calculus"; in the following section the methodological aspects of the study are presented, then the results, the discussion of the results, and finally the conclusions derived from this discussion. 


\section{Profitability of revealing personal information: associated (rational) behaviour}

Information has value. As does (and very much so) personal information, as it has been key to the marketing for more than half a century. The knowledge of who is "on the other side" makes companies and businesses capable of offering products and services adapted to, and therefore more useful to, the client. The digitalisation of economies and societies has not changed the concept, but it has taken it to a new dimension, since data collection is easier and more constant and its exploitation is carried out with much more powerful tools.

The digitalisation of economies and societies has made the collection of data easier and more constant, and this data is exploited with much more powerful tools

Although the study of the use and value of personal information began more than fifty years ago (see the historical review by Gómez-Barroso, 2018), the behaviour of users in this scenario has already begun to be examined in the $21^{\text {st }}$ century. This behaviour is guided by a complex set of factors, different for each individual and with different effect in each situation, and also mediated by heuristics and cognitive biases (see Acquisti; Brandimarte; Loewenstein, 2015). This determines that, since the first studies, the rationality of many of the behaviours related to the disclosure of personal information has been doubted (Acquisti; Grossklags, 2005). In fact, a reflection of this apparent irrationality, known as the "privacy paradox" (what individuals say they would do does not match what they actually do), has dominated much of the research agenda (Kokolakis, 2017, quotes more than 50 works in his bibliographical review). However, the weighting of advantages and disadvantages associated with the voluntary disclosure of personal data (in economic terms, benefits and costs), something that a rational user would do, forms part of many of the models that have tried to understand this behaviour. This is called privacy calculus.

This concept was initially introduced as calculus of behaviour, by Laufer and Wolfe (1977), obviously, given the date, referring to the behaviour in the real world. Culnan and Bies (2003) investigated the idea, stating that in their behaviour as consumers, individuals perform a kind of "cost-benefit analysis" when they must make a conscious decision about whether or not to give up data. Dinev and Hart (2006) are credited with having transposed the concept to the behaviour of individuals on the Internet, although, despite the title of their work, they do not compare benefits and disadvantages but what they call inhibitors and behaviour promoters, including the latter trust and control over the information provided and not the specific benefits derived from the transfer of information. Subsequently other works have continued to use the concept purposely highlighting it (Li; Sarathy; Xu, 2010; Xu et al., 2009; Keith et al., 2013; Wang; Duong; Chen, 2016; Zhu et al., 2017) but more usually hiding it inside more complex models as a piece that alongside other pieces (such as attitude, trust, perception of control, adherence to explicit or subjective norms) tries to respond to the behaviour of individuals.

In any privacy calculus, the cost is evident: data felt as belonging to the personal sphere is transferred and there are an associated risk that the use made of these data will generate discomfort or upset in the future.

The list of benefits is, on the other hand, broader. Hui, Tan and Goh (2006) include the following:

- the gain of time or money, the improvement of self-esteem and adherence to social norms as extrinsic benefits (a means to obtain other objectives);

- pleasure, novelty and altruism as intrinsic benefits (an end in themselves).

It seems clear that the disclosure of personal data basically falls into the first category. It is more useful for our purposes, therefore, Morton's classification (2014), which divides the benefits cited by the participants in a reference group into:

- tangibles: cash payments, cheaper products and services, cost savings;

- intangibles: recommendations, advice on style, ease of visiting shops or portals, removal of the need to reintroduce bank card details, social benefits, socialisation.

How individuals perceive these benefits in a general way is a rarely-studied subject. The most common research in the bibliography measures the effect of offering a concrete benefit in a given situation. Usually, participants in experiments or studies are presented with two scenarios and one of them incorporates an improvement or advantage.

If we restrict ourselves to tangible benefits, we can refer to experiments on the personalisation of applications or services carried out by Chellappa and Sin (2005); Ward, Bridges and Chitty (2005); Sheng, Nah and Siau (2008); Li and Unger (2012); Mothersbaugh et al. (2012); Sutanto et al. (2013) or Kobsa, Cho and Knijnenburg (2016).

The effect of monetary incentives has been analysed by Huberman, Adar and Fine (2005); Curcek et al. (2006); Taylor, Davis and Jillapalli (2009); Premazzi et al. (2010); Carrascal et al. (2011) or Steinfeld (2015).

Many of these studies conclude that individuals respond positively to incentives, that is, when faced with the offer of a certain advantage, the decision about how much information to disclose will change.

The results of these works are always general. Due in many cases to limitations of the study itself (frequently all participants are students, particularly in the case of laboratory experiments), the fact is that none of them has researched the profile of those who are more inclined to exchange personal information for a better (or cheaper) service. It is the main objective of this article. To achieve this, an open survey was conducted with no restrictions on the participation of any person (with a single condition that would ensure the use of a potentially personalised service: the regular use of the Google search engine). 


\section{Perception of benefit: model and results}

\subsection{Methodology}

In September 2016, 1,650 individuals aged 16 and over enrolled in the database of a market research company completed an online survey on their behaviour, attitudes and perceptions regarding the transfer of personal information to service providers and applications susceptible to being personalised. Having been the invitation sent to several thousand people from the database, the participation was controlled by sex, age and autonomous community of residence so that they would respect the percentages of the profile of the Spanish Internet user established in the latest available version of the Survey on equipment and use of information and communication technologies in the homes of the National Institute of Statistics (Instituto Nacional de Estadistica - INE) of Spain. The distribution by sex was exactly $50 \%$ while the distribution by age was as follows:

- $12.97 \%$ under 24 years old;

- 21.52\% between 25 and 34;

- 27.27\% between 35 and 44;

- 21.27\% between 45 and 54;

- 12.36\% between 55 and 64;

- $4.60 \%$ over 64 years old.

Rigorous criteria were applied to identify and rule out potentially invalid answers (incomplete surveys, completed in less than one third of the average time, or an excessively quick first response in any of the sections), which left the number of responses used at 1,436 . The survey contained a block entitled "Perception of benefit" with seven questions and five levels of response, and also 57 questions that served to define the participants not only in socioeconomic terms but also in terms of their activity on the Internet. A questionnaire of 10 true / false questions served to ascertain the users' real knowledge about the management of personal data and its commercial use on the Internet.

Table 1 presents the seven questions that evaluated the benefit that individuals perceive when they disclose data. These are questions elaborated by the authors, since no directly usable antecedent was found in the bibliography. In the works that reveal which questions were used to assess the usefulness of the data transfer, those questions are always linked to a specific service and benefit and therefore they are not useful for a generic evaluation. That said, some of these questions have been adapted to the purpose of this article (specifically some of those used by: Chellappa; Sin, 2005; Xu et al., 2009; Dinev et al., 2013; Kehr et al., 2015). The five answers that were presented were assigned a value of 0 to 4; after summing up, the respondents were classified into three levels, taking the values 7, 20 and 28 as the upper thresholds in each category:

- those who do not (or hardly) perceive benefit in revealing personal information;

- those who perceive a moderate benefit;

- those who perceive a relevant (or a great) benefit in what they obtain in exchange for their data.

The variable "Perception of benefit" was taken as a dependent variable in a multinomial logistic regression model.
Table 1. Survey. Block questions "Perception of benefit"

\begin{tabular}{|c|c|}
\hline $\begin{array}{l}\text { When you reveal personal information you } \\
\text { get a service adapted to your needs }\end{array}$ & \multirow{7}{*}{$\begin{array}{l}\text { Completely agree } \\
\text { Agree } \\
\text { Undecided } \\
\text { In disagreement } \\
\text { In total disagreement }\end{array}$} \\
\hline $\begin{array}{l}\text { When you reveal personal information you } \\
\text { get a free service }\end{array}$ & \\
\hline $\begin{array}{l}\text { When you reveal personal information you } \\
\text { save time in the next visit }\end{array}$ & \\
\hline $\begin{array}{l}\text { When you reveal personal information you } \\
\text { get personalised offers }\end{array}$ & \\
\hline $\begin{array}{l}\text { When you reveal personal information you } \\
\text { can receive money or discounts on the price }\end{array}$ & \\
\hline $\begin{array}{l}\text { When you reveal personal information you } \\
\text { get additional services and/or contents }\end{array}$ & \\
\hline $\begin{array}{l}\text { When you reveal personal information your } \\
\text { internet experience improves }\end{array}$ & \\
\hline
\end{tabular}

Table 2. Survey. Block questions "Internet and mobile phone addiction"

\begin{tabular}{|c|c|}
\hline $\begin{array}{l}\text { Do you find yourself that you have been connected } \\
\text { to the internet for longer than you intended to? }\end{array}$ & \multirow{7}{*}{$\begin{array}{l}\text { Very often } \\
\text { Quite often } \\
\text { Occasionally } \\
\text { Very rarely } \\
\text { Never }\end{array}$} \\
\hline $\begin{array}{l}\text { Do you find that people close to you complain about } \\
\text { the amount of time you spend on the internet? }\end{array}$ & \\
\hline $\begin{array}{l}\text { Does it bother you if someone interrupts you when } \\
\text { you are on the internet? }\end{array}$ & \\
\hline When I'm bored, I use my mobile phone & \\
\hline $\begin{array}{l}\text { I use my phone in situations where, without being } \\
\text { dangerous, it is not appropriate to do so (while } \\
\text { talking to other people, etc.) }\end{array}$ & \\
\hline $\begin{array}{l}\text { I use my phone in situations where it can be dange- } \\
\text { rous (while driving) }\end{array}$ & \\
\hline $\begin{array}{l}\text { When I wake up in the morning, the first thing I do is } \\
\text { see what's new on my phone }\end{array}$ & \\
\hline $\begin{array}{l}\text { I feel lost without my phone - I would go home im- } \\
\text { mediately if I realised that I had forgotten to take it }\end{array}$ & $\begin{array}{l}\text { Definitely } \\
\text { Very likely } \\
\text { Probably } \\
\text { Very unlikely } \\
\text { Never }\end{array}$ \\
\hline
\end{tabular}

Source: Questions taken from the internet addiction test (Young, 1998) and the mobile phone dependency test (Chóliz, 2012)

Table 3. Survey. Block questions "Precedents related to privacy"

\begin{tabular}{|c|c|}
\hline Have you ever been robbed or lost your phone? & \multirow{7}{*}{$\begin{array}{l}\text { Yes } \\
\text { No }\end{array}$} \\
\hline $\begin{array}{l}\text { Has another person ever had access to the contents of your } \\
\text { computer or telephone and had given you the feeling that } \\
\text { your privacy had been violated? }\end{array}$ & \\
\hline $\begin{array}{l}\text { Have any of your internet or email accounts ever been } \\
\text { hacked? }\end{array}$ & \\
\hline $\begin{array}{l}\text { Has your credit card ever been used fraudulently after making } \\
\text { an online payment? }\end{array}$ & \\
\hline $\begin{array}{l}\text { Have you ever been annoyed about the use of your personal } \\
\text { data by a company or website? }\end{array}$ & \\
\hline $\begin{array}{l}\text { Have you ever been annoyed about a message about your } \\
\text { personal life or about a picture of yourself being uploaded by } \\
\text { others without your consent? }\end{array}$ & \\
\hline $\begin{array}{l}\text { Have you ever been annoyed about receiving ads which are } \\
\text { "too personal"? }\end{array}$ & \\
\hline
\end{tabular}

Source: Questions developed by the authors 
As possible independent variables, the following were verified:

- socioeconomic factors: gender, age, couple situation, educational level, employment situation, income, urban characterisation of the place of residence, number of books read;

- basic aspects of Internet connection habits: device, number of hours connected, years using smartphone, types of application;

- activity on the Internet: questions about Internet usage;

- activity in social networks and other platforms: questions about frequency and type of interactions;

- degree of addiction: self control, discomfort due to being disconnected (table 2);

- precedents related to privacy: occurrence of dangerous or unpleasant incidents (table 3);

- knowledge about the subject (table 4).

The analysis began by estimating the validity and reliability of the questionnaire. Predictably, reliability increased by dispensing with many closely related questions, in particular many of those included in the "Basic aspects of internet connection", "Internet activity" and "Activity on social networks and other platforms" groups. The analysis was carried out with the help of the statistical package SPSS, which was also used for the rest of the operations. Once the questionnaire was validated, the logistical regression model chosen was that of "successive steps", not ruling out
Table 4. Survey. Block questions "Real knowledge"

The main source of income for social networks is donations and contributions from users.

If a page publishes its privacy policy, it means that personal information cannot be shared with other companies.

Companies are not allowed to keep the phone number from which a mobile internet session has been established

If you visit webs and blogs about gardening you might start to see ads related to gardening when browsing the web

When certain brands (household names) of telephones or computers are used, personal information is safe

The internet sites of public administrations and governments are not allowed to collect information about users

A cookie is information stored on the computer by a web page so that the user's activity on that page can be remembered in the future.

Companies could automatically explore the content of email or other forms of communication in order to present "most relevant ads"

If the place from which one connects is not revealed, there is no way (even approximate) of knowing where one is

When I'm on a social network, the ads that I see are the same as any other member of the network can see

Source: Questions developed by the authors
Table 5. Results of the model

\begin{tabular}{|c|c|c|c|c|}
\hline & \multirow[t]{2}{*}{ B (Standard error) $)^{\text {Sig }}$} & \multicolumn{3}{|c|}{$\begin{array}{l}95 \% \text { confidence interval } \\
\text { for odds ratio }\end{array}$} \\
\hline & & Lower bound & $\operatorname{Exp}(B)$ & Upper bound \\
\hline \multicolumn{5}{|c|}{ Perception of medium benefit vs. perception of no/little benefit ${ }^{\text {a }}$} \\
\hline Constant & $3.296(0.612)^{* * *}$ & & & \\
\hline Age & $-0.076(0.058)$ & 0.827 & 0.927 & 1.039 \\
\hline Activity - Online purchase & $-0.071(0.085)$ & 0.788 & 0.931 & 1.101 \\
\hline Addiction (joint variable) & $-0.226(0.098)^{*}$ & 0.659 & 0.798 & 0.966 \\
\hline Background (joint variable) & $0.317(0.102)^{* *}$ & 1.125 & 1.373 & 1.675 \\
\hline Knowledge (joint variable) & $-0.202(0.071)^{* *}$ & 0.711 & 0.817 & 0.939 \\
\hline Time in social network & $-0.074(0.075)$ & 0.802 & 0.929 & 1.075 \\
\hline Gender=Man & $-0.108(0.149)$ & 0.670 & 0.897 & 1.201 \\
\hline Gender=Woman & 0 & . & . & . \\
\hline \multicolumn{5}{|c|}{ Perception of great benefit vs. perception of no/little benefit ${ }^{a}$} \\
\hline Constant & $3.795(0.834)^{* * *}$ & & & \\
\hline Age & $-0.089(0.089)$ & 0.768 & 0.915 & 1.090 \\
\hline Activity - Online purchase & $-0.531(0.114)^{* * *}$ & 0.470 & 0.588 & 0.734 \\
\hline Addiction (joint variable) & $-0.737(0.142)^{* * *}$ & 0.362 & 0.478 & 0.632 \\
\hline Background (joint variable) & $0.536(0.151)^{* * *}$ & 1.272 & 1.709 & 2.297 \\
\hline Knowledge (joint variable) & $-0.433(0.104)^{* * *}$ & 0.529 & 0.648 & 0.795 \\
\hline Time in social network & $0.200(0.122)$ & 0.961 & 1.221 & 1.552 \\
\hline Gender $=$ Man & $0.311(0.224)$ & 0.879 & 1.365 & 2.118 \\
\hline Gender=Woman & 0 & . & . & . \\
\hline
\end{tabular}

a The reference category is Perception of no / little benefit

$-R^{2}=0.119$ (Nagelkerke). Proof of likelihood ratio $\chi^{2}(14)=140.187, p<0.001$

-Significativity $* \mathrm{p}<0.05, * * \mathrm{p}<0.01, * * * \mathrm{p}<0.001$ possible interactions between variables. The "main effects" of all the variables selected in that case and also all the possible interactions of the variables taken in pairs were considered in each attempt. As a method of inclusion by steps, "forward entry" was selected. There was no automatic process to select the independent variables considered in each attempt, but the authors repeated the procedure for all feasible sets. Some variables were taken both separately and together (establishing, for example, a single variable of addiction, background or knowledge). The standard criteria of the program on maximum iterations and convergences were maintained.

After this process, the model whose fit presented better accuracy was selected, considering the logarithm of the likelihood and the pseudo- $\mathrm{R}^{2}$ statistic. This model, which does not contain any effect of interaction between variables, obtains the results presented in table 5 . 


\subsection{Analysis of results}

The first part of table 5 shows the estimates of the individual parameters for the moderate benefit category when compared to the reference category (zero or scarce benefit). The interpretation of these effects is as follows:

- The joint background variable (formed by the sum of the answers to the questions presented in table 3 added in three levels) is statistically significant. Since a higher value of this variable corresponds to a lower number of incidents, a positive $B$ coefficient indicates that the fewer incidents that have occurred, the more likely it is that it is considered moderately beneficial to disclose data. The odds ratio (or probabilities or opportunities) is 1.373 which means that the probability that someone considers that it is moderately beneficial to disclose their personal data is increased by that factor for each level that is promoted in the background scale (which as said, grows toward the zero level of incidents or anger).

- The joint variable of knowledge (formed by the sum of the answers to the questions presented in table 4 added in five levels, assessing a correct answer as +1 , an error as -1 and "I don't know" as 0), is also significant. If the variable grows in the direction of "more knowledge" then, given the negative sign, it is more likely that revealing data is considered moderately beneficial the less knowledge one has. The odds ratio is 0.817 which means that it is $1 /$ $0.817=1.244$ times more likely that whoever is in a given level of knowledge is in the category of moderate benefit perception compared to who is in the next level (and has greater knowledge).

- The joint variable of addiction (formed by the sum of the answers to the questions presented in table 2 added in five levels) is, although to a lesser extent, still significant. As in the case of the background, the variable grows in the sense of less addiction, which means that the more addicted, the more the probability of considering moderately beneficial disclosing personal data increases (in particular, it is estimated that the probability varies by $1 / 0.798=$ 1.253 times for each level that is increased).

On the other hand, the second part of table 5 shows the estimates of the individual parameters for the relevant benefit category when compared with the reference category (zero or scarce benefit). The interpretation of these effects in this case is as follows:

- The joint variables of addiction, background and knowledge are highly significant. The meaning is the same as that described above, but in all cases the effect is reinforced (estimate of variation of probabilities by increasing one level: 1.709 for background, 1 / $0.648=1.543$ for knowledge, $1 / 0.478=2.092$ for addiction) .

- The online shopping variable is also highly significant. As the scale of responses began at "every day", the higher the level, the lower the frequency of purchase. The negative sign means then that the less you buy, the lower the probability of perceiving a relevant benefit (according to the odds ratio, the probability is reduced by $1 / 0.588=$ 1.700 per level).
In neither case (neither when the perception of benefit is moderate nor when it is relevant) is gender or age significant. The number of years that a profile has existed in a social network is close to the significance in the level of relevant benefit, but without reaching it. Other variables such as income, educational level, characteristics of the place of residence or family profile are also not significant (nor have they figured in any alternative model evaluated).

\section{Conclusions}

The fact that personal information has become an asset with enormous economic value for companies is something that is beyond doubt. Their clients, however, are not merely passive subjects and victims: their data is also necessary to personalize applications and services, and make them more useful and attractive (Gómez-Barroso; Feijóo, 2013). Knowing who they value, and how much they value, these potential benefits are a key issue for the companies themselves (which seems obvious) but also for those responsible for designing and carrying out policies to protect privacy, because no policy can be effective if one does not know (and adapt to) the social reality in which it is applied.

The results of this article indicate that the perception of benefit obtained when consciously revealing personal data to Internet applications and services is not mediated by socioeconomic characteristics. On the contrary, the characteristics of individuals as Internet users is what counts. In particular, those who seem more likely to perceive greater benefit are: those most addicted to the Internet, those who have not lost their confidence because they have experienced some unpleasant incident on the Internet in the past; those who have less knowledge; and those who develop a greater online activity (they are used to buying or have been registered in a social network for a longer time).

These results, as anticipated, are relevant for companies (to know who or how they run their campaigns) but also for the design of policies. In this sense, it is particularly interesting to note that those who have less knowledge about how they are treated and how their data is managed may have a disadvantage when it comes to valuing benefits and costs or are simply more inclined to value the personalisation of services and applications. The results also have value for future research by showing that the usage categorisation of participants in a survey or study, carried out with socioeconomic parameters, is not sufficient and must be completed with factors of presence in and use of the Internet.

This article has, of course, limitations that may qualify the extension of its conclusions to other contexts. Although studying the perception of benefit without linking it to any pre-established situation has undoubted interest, it does not fail to obtain general results. However, in each specific situation (a specific service offered by a particular provider at a given time) the valuation may be different and it is more than likely that variables such as the type of service, trust in the provider or even the time of day or the place where it is accessed became relevant. After all, the concept of privacy is multidimensional, evolving and dependent on the 
environment, so there is no framework or theory capable of coherently explaining the enormous variety of situations and behaviours. Abundant in this last aspect, the privacy calculus assumes a rational behaviour of the individual; this implies that it is able to independently assign a value to risk and potential benefit and then compare them (Keith; Babb; Lowry, 2014). It is not always the case. As warned when presenting the concept of privacy calculus, individuals, confronted with the decision to give or not to give their data, can act (and do frequently act) in an inconsistent or even irrational way. Assuming all of the above, the interest of any advance in understanding of a phenomenon whose social and economic significance is becoming increasingly evident is undeniable.

\section{Acknowledgments}

The results presented in this article are part of the following research works funded by the Ministerio de Economía y Competitividad of Spain: TUnderstanding personal information-driven markets (ECO2013-47055-R) and Mobile communication and personal information: impact on the content industry, the advertising system and the behaviour of users (CSO2013-47394-R), this in turn coordinated with the $M O B A D$ : The impact of mobile technology on strategic and advertising communication, funded by the Fundación Séneca-Agencia Regional de Ciencia y Tecnología of the Región de Murcia (19451/PI/14).

\section{References}

Acquisti, Alessandro; Brandimarte, Laura; Loewenstein, George (2015). "Privacy and human behavior in the age of information". Science, v. 347, n. 6221, pp. 509-514.

https://www.heinz.cmu.edu/ acquisti/papers/AcquistiScience-Privacy-Review.pdf

https://doi.org/10.1126/science.aaa1465

Acquisti, Alessandro; Grossklags, Jens (2005). "Privacy and rationality in individual decision making". IEEE security \& privacy, v. 3, n. 1, pp. 26-33.

https://www.dtc.umn.edu/weis2004/acquisti.pdf

https://doi.org/10.1109/MSP.2005.22

Carrascal, Juan-Pablo; Riederer, Christopher; Erramilli, Vijay; Cherubini, Mauro; De-Oliveira, Rodrigo (2011). "Your browsing behavior for a big mac: Economics of personal information online". En: Proceedings of the $22^{\text {nd }}$ Intl conf on World Wide Web-WWW'13, pp. 189-200. New York: ACM. ISBN: 9781450320382

https://goo.gl/Tzfsc3

https://doi.org/10.1145/2488388.2488406

Chellappa, Ramnath K.; Sin, Raymond G. (2005). "Personalization versus privacy: An empirical examination of the online consumer's dilemma". Information technology and management, v. 6, n. 2-3, pp. 181-202.

https://goo.gl/yRgFLs

https://doi.org/10.1007/s10799-005-5879-y

Chóliz, Mariano (2012). "Mobile-phone addiction in adolescence: The test of mobile phone dependence". Progress in health sciences, v. 2, n. 1, pp. 33-44. http://progress.umb.edu.pl/sites/progress.umb.edu.pl/ files/33-44\%20Choliz.pdf

Culnan, Mary J.; Bies, Robert J. (2003). "Consumer privacy: Balancing economic and justice considerations". Journal of social issues, v. 59, n. 2, pp. 323-342.

https://goo.gl/ja9w6o

https://doi.org/10.1111/1540-4560.00067

Cvrcek, Dan; Kumpost, Marek; Matyas, Vashek; Danezis, George (2006). "A study on the value of location privacy". En: Procs of the $5^{\text {th }}$ ACM Workshop on privacy in electronic society - WPES '06, pp.109-118. New York: ACM. ISBN: 1 595935568

https://www.esat.kuleuven.be/cosic/publications/article-845.pdf https://doi.org/10.1145/1179601.1179621

Dinev, Tamara; Hart, Paul (2006). "An extended privacy calculus model for e-commerce transactions". Information systems research, v. 17, n. 1, pp. 61-80.

https://doi.org/10.1287/isre.1060.0080

Dinev, Tamara; Xu, Heng; Smith, Jeff; Hart, Paul (2013). “Information privacy and correlates: An empirical attempt to bridge and distinguish privacy-related concepts". European journal of information systems, v. 22, n. 3, pp. 295-316.

https://goo.gl/MrX982

https://doi.org/10.1057/ejis.2012.23

Gómez-Barroso, José-Luis (2018). “Uso y valor de la información personal: un escenario en evolución". El profesional de la información, v. 27, n. 1, pp. 5-18.

https://doi.org/10.3145/epi.2018.ene.01

Gómez-Barroso, José-Luis; Feijóo, Claudio (2013). “Información personal: la nueva moneda de la economía digital". El profesional de la información, v. 22, n. 4, pp. 290-297. https://doi.org/10.3145/epi.2013.jul.03

Huberman, Bernardo A.; Adar, Eytan; Fine, Leslie R. (2005). "Valuating privacy". IEEE security \& privacy, v. 3, n. 5, pp. 22-25.

http://cond.org/deviance.pdf

https://doi.org/10.1109/msp.2005.137

Hui, Kai-Lung; Tan, Bernard C. Y.; Goh, Chyan-Yee (2006). "Online information disclosure: Motivators and measurements". ACM transactions on internet technology, v. 6, n. 4, pp. 415-441.

https://goo.gl/7AYDCw

https://doi.org/10.1145/1183463.1183467

Kehr, Flavius; Kowatsch, Tobias; Wentzel, Daniel; Fleisch, Elgar (2015). "Blissfully ignorant: The effects of general privacy concerns, general institutional trust, and affect in the privacy calculus". Information systems journal, v. 25, n. 6 , pp. 607-635.

https://goo.gl/BDSxUF

https://doi.org/10.1111/isj.12062

Keith, Mark J.; Babb, Jeffry S.; Lowry, Paul-Benjamin (2014). "A longitudinal study of information privacy on mobile devices". En: Procs of the $47^{\text {th }}$ Hawaii int conf on system sciences - Hicss'14, pp. 3149-3158. Washington: IEEE. ISBN: 9781479925049 
https://doi.org/10.1109/hicss.2014.391

Keith, Mark J.; Thompson, Samuel; Hale, Joanne; Lowry, Paul-Benjamin; Greer, Chapman (2013). "Information disclosure on mobile devices: Re-examining privacy calculus with actual user behavior". International journal of human-computer studies, v. 71, n. 12, pp. 1163-1173.

https://goo.gl/Zw85TY

https://doi.org/10.1016/j.ijhcs.2013.08.016

Kobsa, Alfred; Cho, Hichang; Knijnenburg, Bart P. (2016). "The effect of personalization provider characteristics on privacy attitudes and behaviors: An elaboration likelihood model approach". Journal of the Association for Information Science and Technology, v. 67, n. 11, pp. 2587-2606.

https://goo.gl/HBw8By

https://doi.org/10.1002/asi.23629

Kokolakis, Spyros (2017). "Privacy attitudes and privacy behavior: A review of current research on the privacy paradox phenomenon". Computers \& security, v. 64, pp.122-134. https://doi.org/10.1016/j.cose.2015.07.002

Laufer, Robert S.; Wolfe, Maxine (1977). "Privacy as a concept and a social issue: A multidimensional developmental theory". Journal of social issues, v. 33, n. 3, pp. 22-42.

https://goo.gl/qvCuY5

https://doi.org/10.1111/j.1540-4560.1977.tb01880.x

Li, Han; Sarathy, Rathindra; Xu, Heng (2010). "Understanding situational online information disclosure as a privacy calculus". Journal of computer information systems, v. 51, n. 1, pp. 62-71. https://faculty.ist.psu.edu/xu/papers/jcis.pdf

Li, Ting; Unger, Till (2012). "Willing to pay for quality personalization? Trade-off between quality and privacy". European journal of information systems, v. 21, n. 6, pp. 621-642. https://goo.gl/Kgo1PV

https://doi.org/10.1057/ejis.2012.13

Morton, Anthony (2014). "'All my mates have got it, so it must be okay': Constructing a richer understanding of privacy concerns - An exploratory focus group study". En: Gutwirth, Serge; Leenes, Ronald; De-Hert, Paul (eds.). Reloading data protection. Multidisciplinary insights and contemporary challenges, pp. 259-298. Dordrecht; Heidelberg; Londres; New York: Springer. ISBN: 9789400775398 https://doi.org/10.1007/978-94-007-7540-4 13

Mothersbaugh, David L.; Foxx, William K.; Beatty, Sharon E.; Wang, Sijun (2012). "Disclosure antecedents in an online service context: The role of sensitivity of information". Journal of service research, v. 15, n. 1, pp. 76-98.

https://doi.org/10.1177/1094670511424924

Premazzi, Katia; Castaldo, Sandro; Grosso, Monica; Raman, Pushkala; Brudvig, Susan; Hofacker, Charles F. (2010). "Customer information sharing with e-vendors: The roles of incentives and trust". International journal of electronic commerce, v. 14, n. 3, pp. 63-91. https://doi.org/10.2753/jec1086-4415140304

Sheng, Hong; Nah, Fiona-Fui-Hoon; Siau, Keng (2008). “An experimental study on ubiquitous commerce adoption: The impact of personalization and privacy concerns". Journal of Associations for Information Systems, v. 9, n. 6, pp. 344-376. http://aisel.aisnet.org/jais/vol9/iss6/15

Steinfeld, Nili (2015). "Trading with privacy: The price of personal information". Online information review, v. 39, n. 7, pp. 923-938.

https://goo.gl/sTswKG

https://doi.org/10.1108/oir-05-2015-0168

Sutanto, Juliana; Palme, Elia; Tan, Chuan-Hoo; Phang, Chee (2013). "Addressing the personalization-privacy paradox: An empirical assessment from a field experiment on smartphone users". MIS quarterly, v. 37, n. 4, pp. 1141-1164. https://goo.gl/ggf2zr https://doi.org/10.25300/misq/2013/37.4.07

Taylor, David G.; Davis, Donna F.; Jillapalli, Ravi (2009). “Privacy concern and online personalization: The moderating effects of information control and compensation". Electronic commerce research, v. 9, n. 3, pp. 203-223.

https://goo.gl/dsB1mg

https://doi.org/10.1007/s10660-009-9036-2

Wang, Tien; Duong, Trong-Danh; Chen, Charlie C. (2016). "Intention to disclose personal information via mobile applications: A privacy calculus perspective". International journal of information management, v. 36, n. 4, pp. 531-542. https://goo.gl/9MUhx1 https://doi.org/10.1016/j.ijinfomgt.2016.03.003

Ward, Steven; Bridges, Kate; Chitty, Bill (2005). "Do incentives matter? An examination of on-line privacy concerns and willingness to provide personal and financial information". Journal of marketing communications, v. 11, n. 1, pp. 21-40. https://goo.gl/NVh43B https://doi.org/10.1080/1352726042000263575

Xu, Heng; Teo, Hock-Hai; Tan, Bernard C. Y.; Agarwal, Ritu (2009). "The role of push-pull technology in privacy calculus: The case of location-based services". Journal of management information systems, v. 26, n. 3, pp. 135-174. https://goo.gl/Uj6Q48 https://doi.org/10.2753/mis0742-1222260305

Young, Kimberly S. (1998). Caught in the Net: How to recognize the signs of internet addiction and a winning strategy for recovery. New York: John Wiley. ISBN: 9780471191599

Zhu, Hui; Ou, Carol X. J.; Van-den-Heuvel, Willem-Jan A. M.; Liu, Hongwei (2017). "Privacy calculus and its utility for personalization services in e-commerce: An analysis of consumer decision-making". Information \& management, v. 54, n. 4, pp. 427-437.

https://goo.gl/y1CiPo

https://doi.org/10.1016/j.im.2016.10.001 